\title{
ON SUPPOSED REGIONAL VARIATIONS IN TRAVEL TIMES*
}

\author{
By B. Gutenberg
}

IN TWO RECENT PAPERS ${ }^{1,3} \uparrow$ J. B. Macelwane has expressed the idea that "the difference between the travel-time curves of individual earthquakes of the same focal depth but in different regions may be much greater than the differences between our present average curves" and therefore that "it would follow that all our energies should be concentrated on the intensive study of individual earthquakes."'3 The travel times of $\mathrm{P}$ of two Sumatra shocks of 1931 and of a large Solomon Islands shock of that same year, ${ }^{5}$ and the travel-time curves of the $\mathrm{P}$ waves of the Long Beach earthquake ${ }^{8}$ and of the Baffin Bay earthquake, ${ }^{9}$ agree within their limits of error with the travel-time curves published by Gutenberg and Richter. ${ }^{7}$ Furthermore, the travel-time curves last mentioned agree with the travel-time curves published by Jeffreys and Bullen, ${ }^{10}$ in general within one second, and only at distances about $45^{\circ}$ is the difference as large as two seconds. ${ }^{11}$ As these two sets of curves have been found in quite different ways and by using completely different data, there seems to be no doubt that, at least for large parts of the earth's crust, the travel times of the $P$ waves agree within the limits of error.

Unfortunately, various zero points have been used for the travel-time curves. This explains in part the differences found by various authors, as some of them doubtless are not clear about the facts. The author of this paper has always preferred the origin time $O$, that is, the time at which the movement begins at the origin, the hypocenter. This moment is sometimes called "hypocentral time." After a certain time interval, which depends on the local structure and the depth of focus, the first longitudinal waves arrive at the surface. This moment is the "epicentral time." It is about 2 seconds later than the origin time if the shock starts at a depth of $10 \mathrm{~km}$., and about 4 seconds later for a focal depth of $25 \mathrm{~km}$.

Quite different from both is the zero moment chosen by Jeffreys. ${ }^{10,12} \mathrm{He}$ traces the travel-time curve $P_{n}$, which is almost a straight line, back to the epicentral distance 0 and reckons the travel time of $\mathrm{P}$ from this moment, thus eliminating the effect of local structure. The difference between his zero time and the origin time depends on the local structure and the depth of focus. The zero time of the travel-time curves of Gutenberg and Richter is about 6 seconds earlier than that of Jeffreys and Bullen. ${ }^{6,11} \mathrm{It}$ is of importance to realize that Jeffreys has a different zero point for his $\mathrm{S}$ curve: Similar to his procedure with respect to $P$, he traces the $S_{n}$ curve back to the epicentral distance 0 and takes this moment as the zero point for the travel time of $\mathrm{S}$. His travel times of $\mathrm{S}$, therefore, have a zero point which is about 10 seconds later than the one taken by Gutenberg and Richter. As a consequence, his calculated values pTs $^{12}$ do

* Manuscript received for publication September 4, 1937.

$\uparrow$ Superior figures refer to bibliographical references at the end of this paper. 
not give the actual values of $S-P$, but are smaller than these by a constant which depends on the depth of focus and which is about 4 seconds for a focal depth of $25 \mathrm{~km}$.

It is a well-known fact that there are differences in the uppermost parts of the earth's crust in different regions, especially between the bottom of the $\mathrm{Pa}$ cific Basin and other parts of the earth's crust. These differences, however, except for epicentral distances of a few degrees, do not affect the travel times by more than one or two seconds, when shocks with equal depths of focus are investigated.

An exception appears to be the Tango earthquake of March 7, 1927. According to Macelwane and Dahm, ${ }^{4}$ the $\mathrm{P}$ curve of this shock shows maximum deviations of almost 6 seconds at a distance of $65^{\circ}$, about 4 seconds at $20^{\circ}$, and -2 seconds at $10^{\circ}$, and from $30^{\circ}$ to $35^{\circ}$ as compared with the Jeffreys-Bullen curve, and therefore about the same against the Gutenberg-Richter curve. The maximum difference against the $\mathrm{P}$ curve of the Long Beach earthquake is given by Macelwane ${ }^{2}$ as about 9 seconds at a distance of $18^{\circ}$.

This shock has been investigated by many authors, especially by E. A. Hodgson. I shall refer only to the following determinations of its epicenter and origin time:

\begin{tabular}{|c|c|c|c|}
\hline Author & E longitude & N latitude & Origin time \\
\hline T. Matuzawala. & $135^{\circ} 03^{\prime}$ & $35^{\circ} 38^{\prime}$ & \\
\hline Int. Seismol. Summary ${ }^{19}$. & 134.8 & 35.7 & $9^{\mathrm{h}} 27^{\mathrm{m}} 36^{\mathrm{s}}$ \\
\hline E. A. Hodgson ${ }^{14}, 1.5 \ldots \ldots$ & $134^{\circ} 58^{\prime} \cdot 2$ & $35^{\circ} 36^{\prime} .4$ & $92735^{*}$ \\
\hline E. A. Hodgson ${ }^{17}$... & $134^{\circ} 58^{\prime}: 2$ & $35^{\circ} 36^{\prime} \cdot 4$ & 92744 \\
\hline
\end{tabular}

* This time is called "time at origin" in the second paper, 16 whereas Hodgson refers to it as "epicentral time" in the third. 18

Although the epicenters found for this shock agree fairly well, there is apparently some doubt about the origin time. For this reason it seemed advisable to the author to reëxamine the data for this shock, by using the methods published recently by Gutenberg and Richter. ${ }^{20}$

Table 1 contains data of most of the stations up to a distance of $82^{\circ}$ (beginning of SKS), and a few beyond that, as published by the International Seismological Summary. ${ }^{19}$ In this table are given the azimuths of the stations at the I. S. S. epicenter, the distances from that epicenter, and the observed travel times for $\mathbf{P}$ and $\mathbf{S}$, all as given by $\mathbf{I}$. S. S. However, where the times measured by Hodgson differed from the station reports as given by I. S. S., the latter have been replaced by the travel times taken from Hodgson's measurements but using the origin time of I.S. S. The next column gives the differences $S-P$ which correspond to the two preceding columns, and the following the corresponding $P-O$. This has been calculated from table 45 in "Materials for 
TABLE 1

\begin{tabular}{|c|c|c|c|c|c|c|c|c|c|}
\hline Station & $\begin{array}{l}\text { Dist. } \\
\text { (deg.) }\end{array}$ & $\begin{array}{l}\text { Azim. } \\
\text { (deg.) }\end{array}$ & $\underset{(\min .: \mathrm{sec} .)}{\mathrm{P}}$ & $\underset{(\min \text { :sec.) }}{\mathrm{S}}$ & $\mid \begin{array}{c}\mathrm{S}-\mathrm{P} \\
(\mathrm{min} . \mathrm{sec} .)\end{array}$ & $\mid \begin{array}{c}\mathrm{P}-\mathrm{O} \\
(\mathrm{min}: \mathrm{sec} .)\end{array}$ & $\stackrel{\mathrm{O}}{\text { (sec.) }}$ & $\left(\begin{array}{c}\Delta_{\mathrm{P}} \\
\text { deg })\end{array}\right.$ & $\begin{array}{l}\Delta \mathrm{p}-\Delta \\
(\mathrm{deg} .)\end{array}$ \\
\hline Zikawei... & 12.0 & 252 & $3: 01$ & $5: 33$ & $2: 32$ & $3: 12$ & -11 & 12.1 & 0.1 \\
\hline Ootomari....... & 12.4 & 26 & $3: 07$ & $5: 24$ & $2: 17$ & $2: 54$ & 13 & 12.5 & 0.1 \\
\hline Hongkong. . . . . . & 22.4 & 239 & $5: 10$ & & & & & 22.9 & 0.5 \\
\hline Manila... & 24.5 & 214 & $5: 22$ & $9: 56$ & $4: 34$ & $5: 39$ & -17 & 24.1 & -0.4 \\
\hline Irkutsk. & 27.1 & 317 & $5: 49$ & $10: 31$ & $4: 42$ & $5: 48$ & 1 & 27.0 & -0.1 \\
\hline Phu Lien. & 28.8 & 246 & $6: 08$ & $10: 49$ & $4: 41$ & $5: 47$ & 21 & 29.2 & 0.4 \\
\hline Calcutta. & 42.3 & 267 & 8:03 & $14: 09$ & $6: 06$ & $7: 42$ & 21 & 42.5 & 0.2 \\
\hline Simla... & 47.6 & 281 & $8: 48$ & $15: 48$ & 7:00 & $8: 52$ & -4 & 48.2 & 0.6 \\
\hline Batavia........ & 49.5 & 220 & $8: 57$ & $16: 11$ & $7: 14$ & $9: 17$ & -20 & 49.4 & -0.1 \\
\hline Tashkent. . . . . . & 50.4 & 298 & $9: 05$ & $16: 20$ & $7: 15$ & $9: 18$ & -13 & 50.6 & 0.2 \\
\hline Sverdlovsk. & 52.4 & 319 & $9: 14$ & $16: 44$ & $7: 30$ & $9: 22$ & -8 & 51.8 & -0.6 \\
\hline Hyderabad. & 52.8 & 267 & $9: 25$ & $16: 56$ & $7: 31$ & $9: 23$ & 2 & 53.4 & 0.6 \\
\hline Bombay......... & 56.6 & 271 & $9: 47$ & $17: 40$ & $7: 53$ & $9: 47$ & 0 & 56.3 & -0.3 \\
\hline Colombo......... & 57.8 & 255 & $10: 04$ & 18:04 & $8: 00$ & $9: 55$ & 9 & 58.6 & 0.8 \\
\hline Honolulu. . . . . . & 59.6 & 85 & $10: 20$ & $18: 28$ & $8: 08$ & $10: 07$ & 13 & 60.9 & 1.3 \\
\hline Baku. . . & 64.3 & 303 & $10: 45$ & $19: 28$ & $8: 43$ & $10: 51$ & -6 & 64.6 & 0.3 \\
\hline Kucino. , & 64.7 & 322 & $10: 46$ & $19: 26$ & $8: 40$ & $10: 48$ & -2 & 64.7 & 0.0 \\
\hline Pulkovo... & 66.2 & 328 & $10: 52$ & $19: 41$ & $8: 49$ & $10: 59$ & -7 & 65.7 & -0.5 \\
\hline Leningrad. & 66.2 & 328 & $10: 55$ & $19: 44$ & $8: 49$ & $10: 59$ & -4 & 66.2 & 0.0 \\
\hline Tiflis ..... & 67.2 & 306 & $11: 00$ & $19: 56$ & $8: 56$ & $11: 07$ & -7 & 66.9 & -0.3 \\
\hline Suva . . . . . . & 67.8 & 136 & $11: 12$ & & & & & 68.7 & 0.9 \\
\hline Makeevka. & 68.3 & 314 & 11:09 & $20: 07$ & $8: 58$ & $11: 10$ & -1 & 68.3 & 0.0 \\
\hline Helsingfors. & 68.3 & 330 & 11:04 & $20: 04$ & 9:00 & $11: 12$ & -8 & 67.5 & -0.8 \\
\hline Adelaide.... & 70.8 & 177 & $11: 23$ & $20: 36$ & $9: 13$ & $11: 27$ & -4 & 70.6 & -0.2 \\
\hline Victoria........ & 71.0 & 43 & $11: 24$ & $20: 43$ & $9: 19$ & $11: 34$ & -10 & 70.8 & -0.2 \\
\hline Riverview. & 71.2 & 167 & $11: 26$ & $20: 39$ & $9: 13$ & $11: 27$ & -1 & 71.2 & 0.0 \\
\hline Sydney.... & 71.2 & 167 & $11: 30$ & $20: 48$ & $9: 18$ & $11: 33$ & -3 & 71.9 & 0.7 \\
\hline Upsala. ... & 71.5 & 332 & $11: 23$ & $20: 42$ & $9: 19$ & $11: 34$ & -11 & 70.6 & -0.9 \\
\hline Königsberg & 73.4 & 327 & $11: 36$ & $21: 00$ & $9: 24$ & $11: 39$ & -3 & 73.0 & -0.4 \\
\hline Copenhagen & 76.3 & 330 & $11: 56$ & $21: 41$ & $9: 45$ & $12: 01$ & -5 & 76.5 & 0.2 \\
\hline Ksara.... & 77.3 & 303 & $12: 02$ & $21: 53$ & $9: 51$ & $12: 07$ & -5 & 77.4 & 0.1 \\
\hline Berkeley. . & 77.5 & 52 & $12: 02$ & $21: 55$ & $9: 53$ & $12: 09$ & -7 & 77.4 & -0.1 \\
\hline Lick. ... . . & 78.3 & 52 & $12: 09$ & $22: 10$ & $10: 01$ & $12: 16$ & -7 & 78.7 & 0.4 \\
\hline Potsdam... & 78.4 & 328 & $12: 09$ & $22: 02$ & $9: 53$ & $12: 09$ & 0 & 78.7 & 0.3 \\
\hline Hamburg. . . . . . & 78.8 & 330 & $12: 04$ & $22: 07$ & $10: 03$ & $12: 18$ & -14 & 77.8 & -1.0 \\
\hline
\end{tabular}


TABLE 1-(Concluded $)$

\begin{tabular}{|c|c|c|c|c|c|c|c|c|c|}
\hline Station & $\begin{array}{l}\text { Dist. } \\
\text { (deg.) }\end{array}$ & $\begin{array}{l}\text { Azim. } \\
\text { (deg.) }\end{array}$ & $\underset{\text { (min.:sec. }}{\mathbf{P}}$ & $\underset{\text { (min.:sec.) }}{\mathrm{s}}$ & $\underset{(\min .: \text { sec. }}{\mathrm{S}-\mathrm{P}}$ & $\left(\begin{array}{c}\mathrm{P}-\mathrm{O} \\
(\mathrm{min} . \mathrm{sec} .)\end{array}\right)$ & $\underset{\text { (sec.) }}{0}$ & $\left(\begin{array}{l}\Delta_{\mathrm{P}} \\
\text { (deg.) }\end{array}\right.$ & $\begin{array}{l}\Delta \mathrm{p}-\Delta . \\
(\mathrm{deg} .)\end{array}$ \\
\hline Budapest. & 78.9 & 322 & $12: 10$ & 22:17 & 10:06 & $12: 20$ & -9 & 79.2 & 0.3 \\
\hline Praha.... & 79.4 & 324 & $12: 13$ & $22: 15$ & 10:02 & $12: 17$ & -4 & 79.4 & 0.0 \\
\hline Wien . . & 79.7 & 324 & $12: 14$ & $22: 19$ & 10:05 & $12: 20$ & -6 & 79.6 & -0.1 \\
\hline Beograd. & 80.0 & 320 & $12: 16$ & $22: 28$ & $10: 12$ & $12: 26$ & -10 & 80.0 & 0.0 \\
\hline Cheb. & 80.3 & 326 & $12: 18$ & $22: 23$ & 10:05 & $12: 20$ & -2 & 80.4 & 0.1 \\
\hline Graz. . & 80.9 & 323 & $12 ; 22$ & $22: 32$ & $10: 10$ & $12: 24$ & -2 & 81.2 & 0.3 \\
\hline De Bilt. . & 81.8 & 331 & $12: 26$ & $22: 38$ & $10: 12$ & $12: 26$ & 0 & 82.0 & 0.2 \\
\hline Feldberg. & 81.9 & 329 & $12: 27$ & $22: 40$ & $10: 13$ & $12: 27$ & 0 & 82.2 & 0.3 \\
\hline Wellington. & 85.3 & 150 & $12: 44$ & & & & & 85.6 & 0.3 \\
\hline Tucson.... & 88.3 & 50 & $12: 56$ & & & & & 88.0 & -0.3 \\
\hline Algiers. & 94.8 & 323 & $13: 28$ & & & & & 95.0 & 0.2 \\
\hline Cartuja.. & 97.5 & 328 & $13: 42$ & & & & & 98.2 & 0.7 \\
\hline Fordham. & 99.0 & 22 & 13:41 & & & & & 98.0 & -1.0 \\
\hline
\end{tabular}

the Study of Deep-Focus Earthquakes," by Gutenberg and Richter. ${ }^{21}$ This table begins with an $S-P$ of one minute. The following corresponding values of $S-P$ and $P-O$ have been added for normal depth of focus:

$\begin{array}{lllllll}S-P & 10 & 20 & 30 & 40 & 50 & \text { seconds } \\ P-O & 14 & 27 & 39 & 52 & 65 & \text { seconds }\end{array}$

The ratio $(P-O) /(S-P)$ depends only on Poisson's Ratio, not on the absolute values of the velocities and, therefore, this method of finding $O$ depends very little on the local structure. The column headed $O$ in table 1 gives the origin time calculated from the data of each station by subtracting the value for $P-O$ in column 6 from the travel time of $\mathrm{P}$ (column 4) from the origin time of I. S. S. The average of these origin times is -3 seconds. However, as has been pointed out, ${ }^{20}$ the value for the origin time found in this way from teleseismic records is usually 6 seconds too early, partly because $S$ is frequently measured too late, partly because of the incorrectness of table 45 used for the calculation. This table 45 is to be improved in a paper not yet finished.

Thus we find as the most probable origin time of the Tango earthquake: $9^{\mathrm{h}} 27^{\mathrm{m}} 36^{\mathrm{s}}+3^{\mathrm{s}}=9^{\mathrm{h}} 27^{\mathrm{m}} 39^{\mathrm{s}}$. The column headed " $\Delta \mathrm{P}$ " of table 1 gives the distance found by using table 1 of Gutenberg and Richter" for a normal earthquake. Finally, the last column gives the differences of the distance found in this way minus the distance given by I. S. S. These differences have been plotted in figure 1 as a function of the azimuth. As may be seen, the residuals are about the same irrespective of the azimuth, indicating that the assumed 
epicenter is not incorrect by more than about $1 / 4$ degree. There seems, however, to be a slight predominance of positive values in the neighborhood of $320^{\circ}$, apparently indicating the necessity of a slight shift, to the southeast, of the epicenter adopted by I. S. S., which would bring it very close to the epicenter found by Hodgson.

In a similar way the values published by Matuzawa ${ }^{19}$ for the near-by Japanese stations have been used. In table $2 a$ the values are given for distances up to

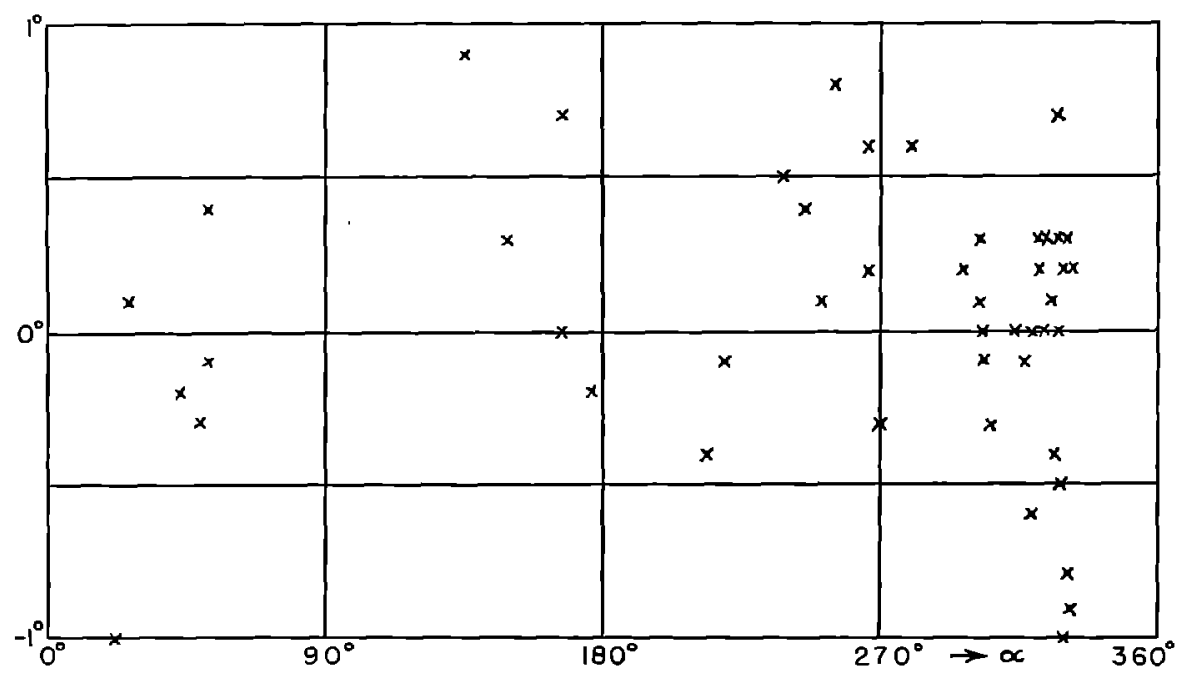

Fig. 1. Differences $\Delta_{\mathbf{P}^{-}} \Delta$ (last column of table 1) as functions of azimuth.

$3^{\circ}$ as in table 1 , except (1) that the time found just above, $9^{\mathrm{h}} 27^{\mathrm{m}} 39^{\mathrm{s}}$, has been taken as origin time, and (2) that the epicenter is that adopted by Matuzawa. The column " $O$ " gives the residuals referred to $9^{\mathrm{h}} 27^{\mathrm{m}} 39^{\mathrm{s}}$ as origin time. As their average is zero, it shows that the origin time as adopted is very closely correct. It scarcely could be wrong by 2 seconds; for under this assumption the residuals given in the last columns of tables 1 and 2 would change systematicaly with the distance, and this does not occur. The rest of data of the Japanese stations for distances beyond 3 degrees are given in table $2 b$. No use has been made of the $\mathbf{S}$ phases for these larger distances, as it is not accurate enough, owing to the small amplitude of $S_{n}$ at these distances. Figure 2 shows the residuals in distance (similarly to fig. 1) for the near-by stations; again there are no large systematic errors. Probably a shift of the epicenter assumed by Matuzawa, which has been used in figure 2 , by 0.1 toward the west, corresponding to the prevailing small positive residuals near $\Delta=90^{\circ}$, would improve it somewhat. In this way we find again that the epicenter assumed by Hodgson is probably the best and can hardly be wrong by more than $15 \mathrm{~km}$. 
TABLE 20

\begin{tabular}{|c|c|c|c|c|c|c|c|c|}
\hline Station & $\begin{array}{l}\text { Azim. } \\
\text { (deg.) }\end{array}$ & $\begin{array}{l}\text { Dist. } \\
\text { (deg.) }\end{array}$ & $\underset{\text { (see.) }}{\mathbf{P}}$ & $\underset{(\mathrm{sec} .)}{\mathrm{S}-\mathrm{P}}$ & $\begin{array}{l}\mathrm{P}-\mathrm{O} \\
\text { (sec.) }\end{array}$ & $\underset{\text { (sec.) }}{0}$ & $(\stackrel{\Delta}{\text { deg.) }})$ & $\begin{array}{l}\Delta_{\mathrm{p}}-\Delta \\
(\operatorname{deg},)\end{array}$ \\
\hline Miyazu.... & 140 & 0.2 & 6 & & & & 0.2 & 0.0 \\
\hline Toyooka. & 260 & 0.2 & 6 & 3 & 7 & -1 & 0.2 & 0.0 \\
\hline Kyôto.... & 140 & 0.8 & 18 & 15 & 21 & -3 & 0.9 & 0.1 \\
\hline Kôbe..... & 170 & 1.0 & 19 & & & & 1.0 & 0.0 \\
\hline Osaka.......... & 160 & 1.0 & 18 & 17 & 24 & -6 & 0.9 & -0.1 \\
\hline Hikone. & 100 & 1.0 & 21 & 18 & 25 & -4 & 1.1 & 0.1 \\
\hline Hukui. . & 70 & 1.1 & 20 & 17 & 24 & -4 & 1.1 & 0.0 \\
\hline Yagi.. & 150 & 1.3 & 24 & 16 & 23 & 1 & 1.3 & 0.0 \\
\hline Sumoto.... & 190 & 1.3 & 19 & 18 & 25 & -6 & 1.0 & -0.3 \\
\hline Okayama.. & 220 & 1.3 & 30 & 18 & 25 & 5 & 1.7 & 0.4 \\
\hline Gihu... & 90 & 1.4 & 22 & 20 & 27 & -5 & 1.2 & -0.2 \\
\hline Wakayama. & 180 & 1.4 & 26 & 20 & 27 & -1 & 1.5 & 0.1 \\
\hline Sakai....... & 270 & 1.5 & 24 & 13 & 19 & 5 & 1.3 & -0.2 \\
\hline Tu.... & 140 & 1.5 & 28 & & & & 1.6 & 0.1 \\
\hline Nagoya & 100 & 1.6 & 31 & 25 & 33 & -2 & 1.7 & 0.1 \\
\hline Tokusima. & 200 & 1.6 & 40 & 23 & 31 & 9 & 2.4 & 0.8 \\
\hline Tadotu.......... & 220 & 1.7 & 39 & & & & 2.3 & 0.6 \\
\hline Takayama....... & 70 & 1.9 & 26 & 20 & 27 & -1 & 1.5 & -0.4 \\
\hline Husiki..... & 50 & 2.0 & 37 & 24 & 32 & 5 & 2.2 & 0.2 \\
\hline Hirosima. & 250 & 2.1 & 30 & & & & 1.7 & -0.4 \\
\hline Sisakasima. & 230 & 2.2 & 26 & & & & 1.5 & -0.7 \\
\hline Niihama... & 220 & 2.2 & 25 & & & & 1.4 & -0.8 \\
\hline Iida...... & 90 & 2.3 & 30 & 30 & 39 & -9 & 1.7 & -0.6 \\
\hline Siomisaki. & 170 & 2.3 & 51 & 30 & 39 & 12 & 3.2 & 0.9 \\
\hline Kôti...... & 210 & 2.4 & 39 & 34 & 44 & -5 & 2.3 & -0.1 \\
\hline Kure......... & 240 & 2.5 & 53 & & & & 3.3 & 0.8 \\
\hline Matumoto...... & 80 & 2.5 & 48 & & & & 3.0 & 0.5 \\
\hline Hamada. . . . . . . . & 260 & 2.5 & 40 & 29 & 38 & 2 & 2.4 & -0.1 \\
\hline Matuyama...... & 230 & 2.6 & 49 & 36 & 47 & 2 & 3.0 & 0.4 \\
\hline Nagano.... & 60 & 2.7 & 46 & & & & 2.8 & 0.1 \\
\hline Kohu. . & 90 & 2.9 & 61 & & & & 3.8 & 0.9 \\
\hline Takada.... & 60 & 3.0 & 52 & 37 & 48 & 4 & 3.3 & 0.3 \\
\hline
\end{tabular}

Finally, table 3 gives the travel times for $\mathrm{P}$ for those stations which have been found by Hodgson to have clear records of $\mathrm{P}$. All data which he has put in parentheses, indicating some doubt, have been omitted, except that for Sverdlovsk the time reported by the station has been retained. The distances are 
TABLE $2 b$

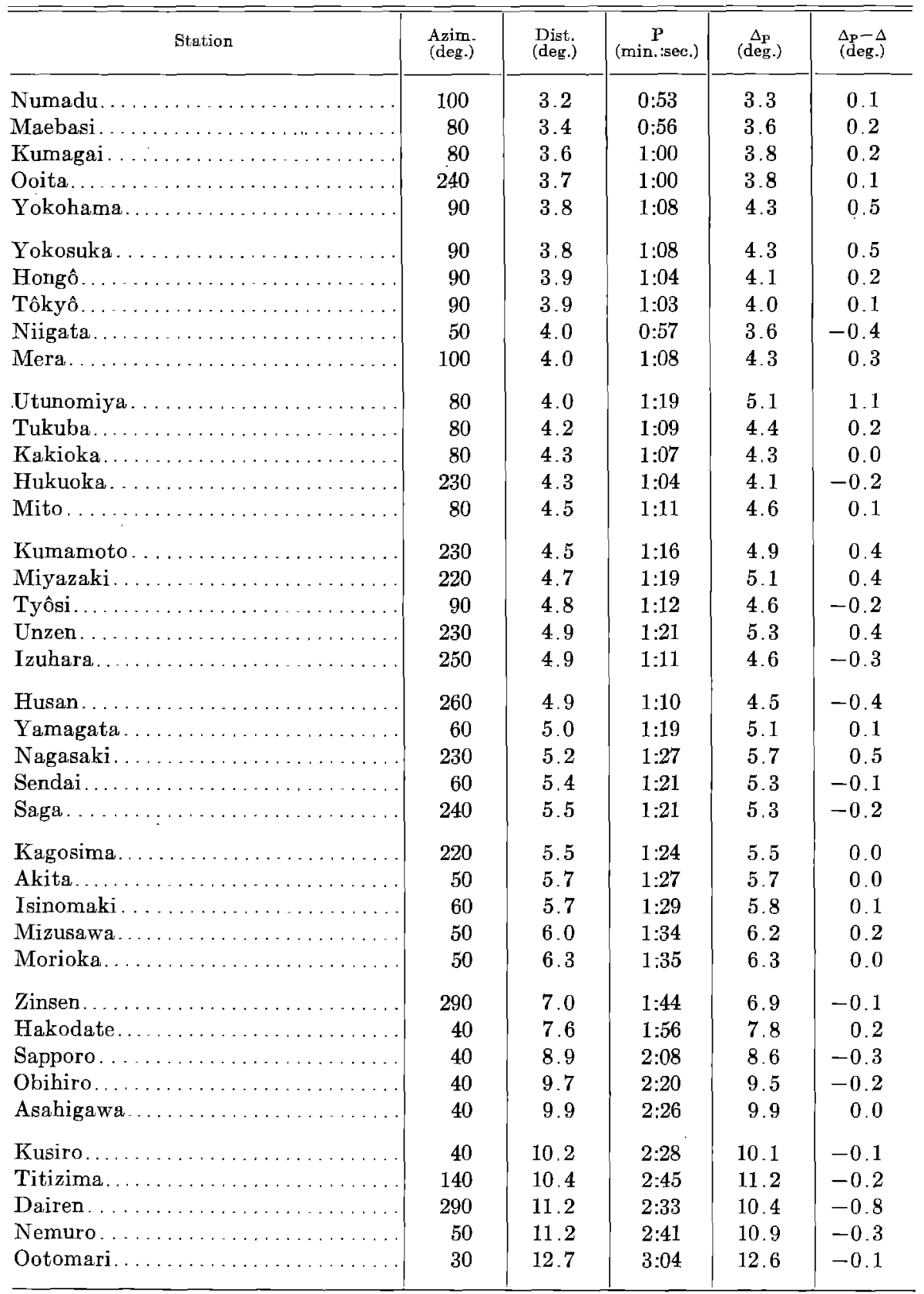


TABLE 3

\begin{tabular}{|c|c|c|c|c|}
\hline \multirow{2}{*}{ Station } & \multirow{2}{*}{$\begin{array}{l}\text { Dist. } \\
\text { degr. }\end{array}$} & \multicolumn{3}{|c|}{ Travel time of $P$ in min.sec. } \\
\hline & & observed & calculated & obs,-calc. \\
\hline $\begin{array}{l}\text { Kobe } \ldots \ldots \ldots \ldots \\
\text { Sumoto } \ldots \ldots \ldots \\
\text { Kôti } \ldots \ldots \\
\text { Nagano } \ldots \ldots \\
\text { Tôkyô. } \ldots \ldots \\
\end{array}$ & $\begin{array}{l}0.9 \\
1.3 \\
2.4 \\
2.8 \\
3.9\end{array}$ & $\begin{array}{l}0: 19 \\
0: 25 \\
0: 41 \\
0: 46 \\
1: 03\end{array}$ & $\begin{array}{l}0: 19 \\
0: 24 \\
0: 40 \\
0: 46 \\
1: 02\end{array}$ & $\begin{array}{l}0 \\
1 \\
1 \\
0 \\
1\end{array}$ \\
\hline 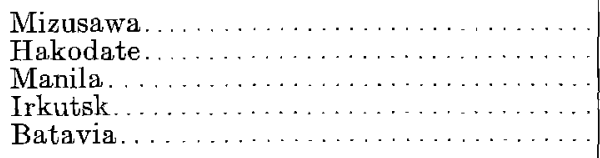 & $\begin{array}{r}6.0 \\
7.6 \\
24.5 \\
27.3 \\
49.5\end{array}$ & $\begin{array}{l}1: 34 \\
1: 56 \\
5: 19 \\
5: 46 \\
8: 54\end{array}$ & $\begin{array}{l}1: 31 \\
1: 54 \\
5: 22 \\
5: 48 \\
8: 54\end{array}$ & $\begin{array}{r}3 \\
2 \\
-3 \\
-2 \\
0\end{array}$ \\
\hline $\begin{array}{l}\text { Sverdlovsk } \\
\text { Baku. . } \\
\text { Kucino } \ldots \ldots \ldots \\
\text { Abisko } \ldots \ldots \\
\text { Pulkovo } \ldots \ldots\end{array}$ & $\begin{array}{l}52.6 \\
64.5 \\
64.8 \\
65.9 \\
66.1\end{array}$ & $\begin{array}{r}9: 15 \\
10: 42 \\
10: 43 \\
10: 47 \\
10: 49\end{array}$ & $\begin{array}{r}9: 16 \\
10: 41 \\
10: 43 \\
10: 49 \\
10: 51\end{array}$ & $\begin{array}{r}-1 \\
1 \\
0 \\
-2 \\
-2\end{array}$ \\
\hline 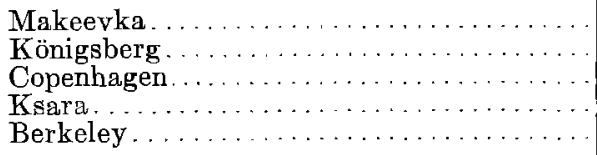 & $\begin{array}{l}68.1 \\
73.6 \\
76.4 \\
77.4 \\
77.6\end{array}$ & $\begin{array}{l}11: 06 \\
11: 33 \\
11: 53 \\
11: 59 \\
11: 59\end{array}$ & $\begin{array}{l}11: 04 \\
11: 34 \\
11: 51 \\
11: 57 \\
11: 58\end{array}$ & $\begin{array}{r}2 \\
-1 \\
2 \\
2 \\
1\end{array}$ \\
\hline 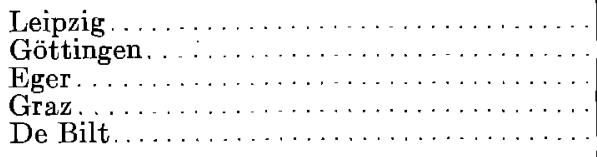 & $\begin{array}{l}79.6 \\
80.5 \\
80.5 \\
81.2 \\
82.0\end{array}$ & $\begin{array}{l}12: 09 \\
12: 14 \\
12: 15 \\
12: 19 \\
12: 33\end{array}$ & $\begin{array}{l}12: 10 \\
12: 14 \\
12: 14 \\
12: 18 \\
12: 22\end{array}$ & $\begin{array}{r}-1 \\
0 \\
1 \\
1 \\
1\end{array}$ \\
\hline 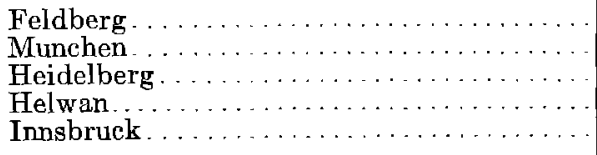 & $\begin{array}{l}82.1 \\
82.2 \\
82.6 \\
82.9 \\
83.0\end{array}$ & $\begin{array}{l}12: 24 \\
12: 24 \\
12: 26 \\
12: 28 \\
12: 25\end{array}$ & $\begin{array}{l}12: 23 \\
12: 23 \\
12: 25 \\
12: 27 \\
12: 27\end{array}$ & $\begin{array}{r}1 \\
1 \\
1 \\
1 \\
-2\end{array}$ \\
\hline 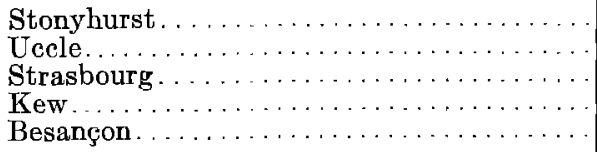 & $\begin{array}{l}83.3 \\
83.3 \\
83.6 \\
84.5 \\
85.4\end{array}$ & $\begin{array}{l}12: 25 \\
12: 27 \\
12: 30 \\
12: 35 \\
12: 41\end{array}$ & $\begin{array}{l}12: 28 \\
12: 28 \\
12: 30 \\
12: 35 \\
12: 39\end{array}$ & $\begin{array}{r}-3 \\
-1 \\
0 \\
0 \\
2\end{array}$ \\
\hline 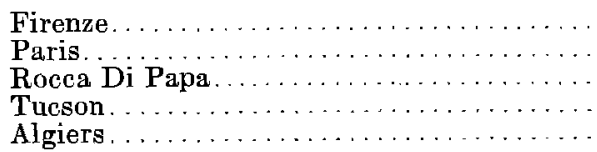 & $\begin{array}{l}85.6 \\
85.6 \\
86.4 \\
88.3 \\
94.9\end{array}$ & $\begin{array}{l}12: 43 \\
12: 41 \\
12: 39 \\
12: 53 \\
13: 25\end{array}$ & $\begin{array}{l}12: 40 \\
12: 40 \\
12: 44 \\
12: 53 \\
13: 24\end{array}$ & $\begin{array}{r}3 \\
1 \\
-5 \\
0 \\
1\end{array}$ \\
\hline $\begin{array}{l}\text { Toledo } \ldots \ldots \ldots \ldots \ldots \ldots \ldots \ldots \ldots \ldots \ldots \ldots \ldots \\
\text { Cartuja } \ldots \ldots \ldots \ldots \ldots \ldots \ldots \ldots\end{array}$ & $\begin{array}{l}95.6 \\
97.7\end{array}$ & $\begin{array}{l}13: 31 \\
13: 39\end{array}$ & $\begin{array}{l}13: 27 \\
13: 36\end{array}$ & $\begin{array}{l}4 \\
3\end{array}$ \\
\hline
\end{tabular}




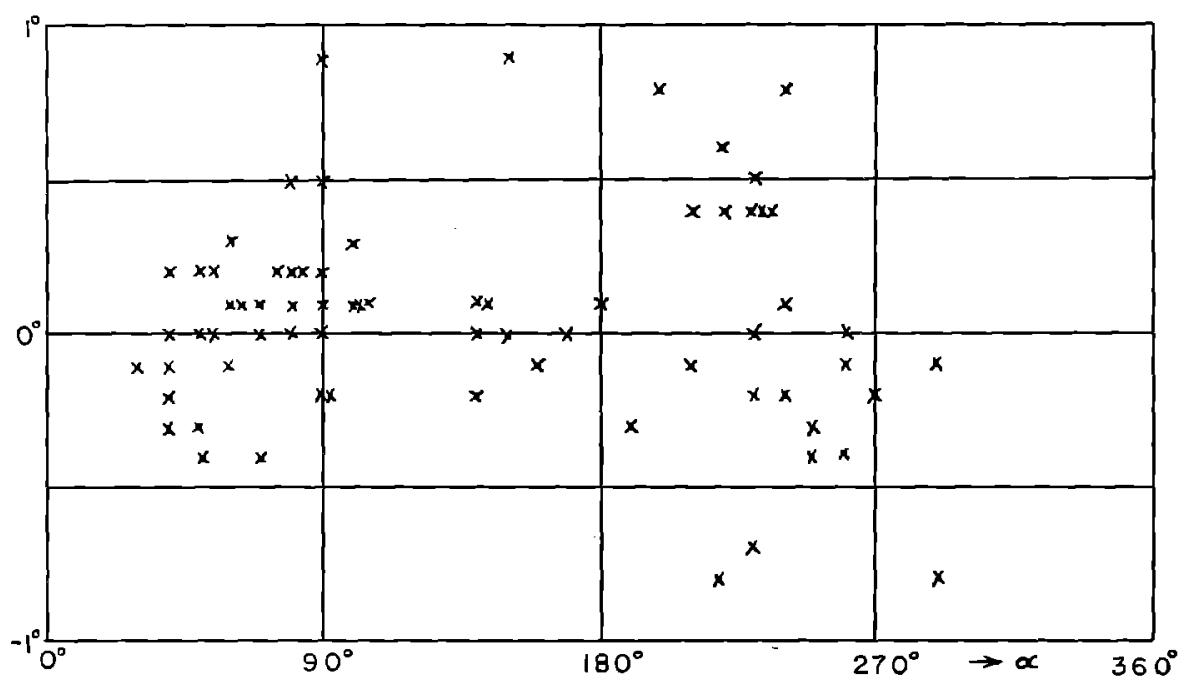

Fig. 2. Differences $\Delta_{\mathbf{p}}-\Delta$ (last columns of tables $2 a$ and $2 b$ ) as functions of azimuth.

those given by Hodgson; the origin time is the one found in this paper $\left(9^{\mathrm{h}} 27^{\mathrm{m}}\right.$ $\left.39^{s}\right)$.The third column contains the travel times which correspond to the travel-time curves of Gutenberg and Richter ${ }^{7}$ for the given distances. The last column, finally, contains the residuals, and there is no doubt that these are within the limits of error to be expected for the stations in 1927. In figure 3 the

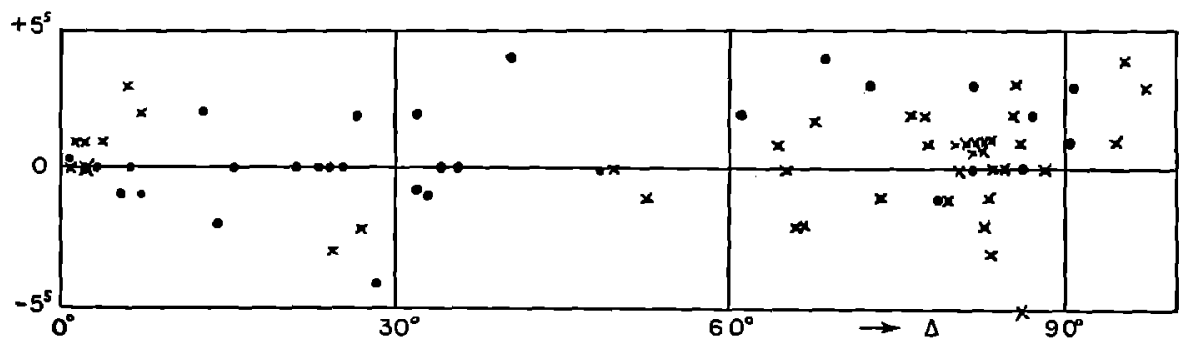

Fig. 3. Observed travel times of $P$ minus travel times from the Gutenberg-Richter table $^{7}$ for the Tango earthquake (crosses) and the Long Beach earthquake (dots).

residuals of the $\mathbf{P}$ waves of the Tango earthquake (crosses) and of the Long Beach earthquake (dots) against the values given by Gutenberg and Richter ${ }^{7}$ are plotted together. Neither in this figure nor in tables 1-3 is there any indication that the $P$ waves of the Tango earthquake had travel times different by more than a second or two, either from the shocks investigated in detail in various publications or from the travel-time curves published by Gutenberg and Richter or by Jeffreys and Bullen. 
The $\mathrm{P}$ waves of the Tango earthquake are not very favorable to the construction of a new travel-time curve, for two reasons. First, as already stated by Hodgson, ${ }^{22}$ there are large ranges of distances with very few observations. Second, it is evident from figures 1 and 2 that the scattering of the residuals is slightly larger than usual in recent shocks and that for this reason and the unusually large number of doubtful beginnings, as marked by Hodgson, the $\mathrm{P}$ waves of the Tango earthquake cannot be considered as among the best observed. This had been found already by Jeffreys and Bullen, ${ }^{23}$ who have therefore rejected the data.

\section{SUMMARY}

An investigation of the Tango earthquake of March 7, 1927, shows that travel times for P observed in that shock agree within the limits of error of one or two seconds with the travel times found for other earthquakes and that thus far there is no indication of differences beyond the limits of observational errors between the travel-time curves of earthquakes in different regions. This statement, however, does not include the travel times to short epicentral distances of a few degrees found in various regions which are influenced by the local structures in those regions, and especially not to the travel times found from waves which have traversed only the uppermost parts under the Pacific Ocean. 


\section{REFERENCES}

${ }^{1}$ J. B. Macelwane, "Roots of Mountains or Roots of Continents?" Bull. Seism. Soc. Am., $27: 29-33$ (1937).

2 Ibid., upper part of fig. 1, p. 30.

"J. B. Macelwane and C. G. Dahm, "Revised Travel Time Tables," Publ. Bur. Centr. Seism. Int., ser. A, fasc. 15, 1e partie, pp. $87-92$ (1937); also mimeographed, St. Louis, September, 1936.

${ }^{4}$ Ibid., fig. 1, p. 88, of printed paper and p. 2 of mimeographed.

`B. Gutenberg and C. F. Richter, "On Seismic Waves (First Paper)," Gerlands Beitr. z. Geophysik, 43:56-133 (1934).

Ibid., p. 65.

7 Ibid., p. 82.

${ }^{8}$ B. Gutenberg, "The Propagation of the Longitudinal Waves Produced by the Long Beach Earthquake," Gerlands Beitr. z. Geophysik, 41:114-120 (1934); see esp. p. 119.

${ }^{9}$ A. W. Lee, "On the Travel of Seismic Waves from the Baffin Bay Earthquake of November 20, 1933," Meteorol. Office, Geophys. Memoirs, no. 74 (London, 1937), pp. 10-11.

${ }^{10}$ H. Jeffreys and K. E. Bullen, "Times of Transmission of Earthquake Waves," Publ. Bur. Centr. Seismol., Trav. Scientif., fase. 11 (1935); see esp. pp. 90-93.

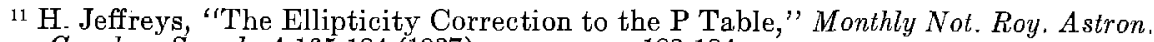
Soc., Geophys. Suppl., 4:165-184 (1937); see esp. pp. 183-184.

${ }^{12} \mathrm{H}$. Jeffreys, "Tables of the Times of Transmission of the P \& S Waves of Earthquakes," British Assoc. Adv. Sci., Gray-Milne Trust (1932).

1. T. Matuzawa, "Observation of Some Recent Earthquakes and Their Time-Distance Curves," Bull. Earthq. Res. Inst. Tokyo, 5:1-28 (1928); esp. pp. 7-9.

${ }^{14}$ E. A. Hodgson, "Two Probability Methods for the Determination of Earthquake Epicenters," Gerlands Beitr. z. Geophysik, 37:390-409 (1932).

${ }^{15}$ E. A. Hodgson, "The P-Curve and the S-Curve Resulting from a Study of the Tango Earthquake, Japan, March 7, 1927," Bull. Seism. Soc. Am., 22:38-49 (1932).

${ }^{16}$ Ibid., p. 38.

${ }^{1 \tau}$ E. A. Hodgson, "Epicentral Time and Surface Structure Determined from the Tango Earthquake, Japan, March 7, 1937," Bull. Seism. Soc. Am., 22:270-287 (1932).

18 Ibid., p. 276.

${ }^{19}$ H. H. Turner, The International Seismological Summary for 1927, January, February, March (Oxford, 1930), pp. 68-71.

${ }^{20}$ B. Gutenberg and C. F. Richter, "Materials for the Study of Deep-Focus Earthquakes (Second Paper)," Bull. Seism. Soc. Am., 27:157-183 (1937).

${ }^{21}$ B. Gutenberg and C. F. Richter, "Materials for the Study of Deep-Focus Earthquakes," Bull. Seism. Soc. Am., 26:341-390 (1936).

${ }^{22}$ E. A. Hodgson, reference ${ }^{15}$, p. 49.

${ }^{23}$ H. Jeffreys and K. E. Bullen, reference ${ }^{10}$, p. 33 .

Balch Graduate School of the Geological Sctences,

California Institute of Technology [Contribution No. 241].

Pasadena, California. 